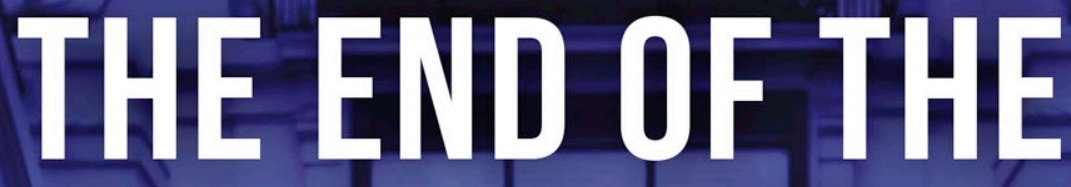

SIALL PARTY?

Change UK and the challenges of parliamentary politics 


\section{The end of the small party?}

\section{MANCHESTER 1824}

Manchester University Press 
Louise Thompson - 9781526153029

Downloaded from manchesterhive.com at $04 / 26 / 2023$ 03:27:13PM 


\section{The end of the small party?}

Change UK and the challenges of parliamentary politics

\section{Louise Thompson}

Manchester University Press 
Copyright (C) Louise Thompson 2020

The right of Louise Thompson to be identified as the author of this work has been asserted by him/her in accordance with the Copyright, Designs and Patents Act 1988.

Published by Manchester University Press

Altrincham Street, Manchester Mi 7JA

www.manchesteruniversitypress.co.uk

British Library Cataloguing-in-Publication Data

A catalogue record for this book is available from the British Library

ISBN 978 I 526I 4558 I hardback

First published 2020

The publisher has no responsibility for the persistence or accuracy of URLs for any external or third-party internet websites referred to in this book, and does not guarantee that any content on such websites is, or will remain, accurate or appropriate.

COVER IMAGE: Chris J. Ratcliffe, 'Conservative MPs Resign to Join The Independent Group'

(Getty Images)

Typeset

by New Best-set Typesetters Ltd 